\title{
Resumen
}

La investigación pretende establecer que existe una conexión histórica entre las actuales organizaciones transnacionales de crimen organizado con los piratas, contrabandistas y bandidos que operaron durante la época de la colonia española en el área Mesoamericana y El Caribe. El trabajo sostiene que el factor que liga a unos y otros, es el hecho que ambos tipos de actores ilegales comparten el mismo esquema mental: la mentalidad burguesa. Ésta última se caracteriza por su racionalidad, su pretensión de dominio sobre el mundo, la valoración del ascenso socio-económico y la acumulación de riqueza. Asimismo se sostiene que en la misma forma que las actividades ilegales de piratas, contrabandistas y bandidos incidieron en el declive del imperio español en América, el accionar de grupos del crimen organizado está en el presente amenazando la viabilidad de los Estados Nacionales en el área Mesoamericana y del Caribe.

\section{El crimen}

\section{organizado en}

Mesoamérica y el

\section{Palabras Clave}

Crimen organizado, Caribe, Mesoamérica, colonia, piratería, contrabando.

Caribe: Legado

de piratas,

contrabandistas y bandidos*

Juan Ricardo

Gómez Hecht

Recibido: noviembre 12 de 2012 Aceptado: diciembre 12 de 2012

* Artículo académico original presentado al Centro de Investigación Científica (CINC-ANSP) para su publicación en la revista "Policía y Seguridad Pública". 


\section{Abstract}

Organized crime appears as a recurrent phenomenon in the actual social conditions of the world order. It exhibits different expressions, from extremely violent configurations to highly refined forms. This means that the approach toward criminal organizations requires different perspectives. This determines the importance of the concept of organized crime, and, in this regard, this paper intends to address this framework, and deal with it based on the characteristics that criminal organizations share. It also examines the way the legal concept of organized crime has evolved in El Salvador, and the problematic aspects of interpretation present in the conceptual framework that has defined it, from the perspective of the creation of the concept of organized crime in the Criminal Code, to the most recent laws that affect this phenomenon such as the Law Prohibiting Gangs, Groups, Association and Organizations of a Criminal

Organized Crime in Mesoamerica and the Caribbean: Legacy of Pirates, Smugglers and Bandits*

\author{
Juan Ricardo \\ Gómez Hecht
}

Sumitted: November 12, 2012 Accepted: December 12, 2012
Nature.

\section{Key words}

Organized Crime, criminal groups, gangs, criminal organizations with a commanding order, stratified hierarchy.

* Original academic article presented to the Scientific Investigation Center (CINC.ANSP) for publication in the journal "Police and Public Security." 


\section{Introducción}

Surcan las mismas aguas, persiguen el mismo fin, se dedican a actividades similares, se desenvuelven en la misma área geográfica, recurren a las mismas prácticas, sin embargo los separan más de 300 años de diferencia. Los unos son piratas, contrabandistas y bandidos, se guiaban por las estrellas y su olfato depredador; los otros son miembros de grupos de crimen organizado y disponen de los sistemas más avanzados de posicionamiento global.

Ambos grupos representaron y representan el mayor peligro para el orden establecido: los piratas, contrabandistas y bandidos para la América española, los grupos de crimen organizado lo han sido y lo son, para los modernos Estados nacionales. Cada fenómeno es singular en el tiempo y espacio en que se desarrolla y a pesar de eso conforman una compleja unidad histórica. Ambas objetivaciones de la subcultura criminal se constituyen en hechos históricos en sí, que se dan en determinadas coyunturas pero al final son partes de un mismo proceso de larga duración ${ }^{1}$. Diferencias abismales, no solo de tiempo, los separan pero al final devienen en lo mismo, unos representan el pasado, los otros el presente. ¿Qué los vincula?

El presente trabajo pretende dar respuesta a esta interrogante partiendo de la tesis que en la misma forma en que las actividades ilegales de piratas, contrabandistas y bandidos incidieron en el declive del imperio español en América, el accionar de grupos del crimen organizado están, en el presente, amenazando la viabilidad de los Estados nacionales en el área Mesoamericana y del Caribe, el vínculo entre unos y otros lo constituye el hecho de que comparten el mismo esquema mental: la mentalidad burguesa. Ésta última se caracteriza por su racionalidad, su pretensión de dominio sobre el mundo, la valoración del ascenso socio-económico y la acumulación de riqueza.

En este orden de ideas, el punto de partida de reflexión son los aportes teóricos del historiador argentino José Luis Romero, sobre todo, aquellos generados por su preocupación en el surgimiento del tipo de mentalidad señalado; la centralidad de las ciudades en la conformación de la identidad cultural latinoamericana; y su interés en explicar estos fenómenos a través

1. Proceso de larga duración es un concepto acuñado por el historiador francés Fernand Braudel, que implica una relación histórica que permite una aproximación abierta y experimental a la recons trucción teórica del cambio histórico del mundo a largo plazo y en gran escala. Se refiere a la lentísima dinámica de cambio del tiempo histórico, forma la interface del mundo físico natural y la actividad social humana, del espacio físico y del espacio humano, proveyendo el elemento unificador de su historia (Tor nich, 2008, p. 2-3). 
de estudios de procesos de larga duración. El estudio se enfoca en este contexto teórico por considerar que el mismo revierte el mayor poder explicativo para la apreciación de los detalles de la causalidad imbuida en la relación dinámica de los hechos que permiten una mayor dilucidación del objeto de estudio.

A pesar de que tanto el surgimiento de los piratas, contrabandistas y bandidos, como la aparición de grupos de crimen organizado, se reprodujeron y reproducen en toda el área americana, el estudio se limita a estudiar ambos fenómenos como formas concretas de vida, productos de la cultura de su tiempo, en el área Mesoamericana y del Caribe, en que irónicamente, su ubicación en el globo terráqueo, se convierte a la vez en una ventaja, - con tierras ricas en diversidad de flora y fauna, como puente de comercio y en punto de contacto de culturas-, como también deviene en desventaja al constituirse en una zona de tránsito de contrabando y tráfico ilegal de bienes, armas y personas con una elevada actividad criminal, reducto de lavado de activos y otro tipo de transacciones ilícitas y base de las operaciones de organizaciones criminales de carácter transnacional.

En el Capítulo I se explica el concepto y características de la mentalidad burguesa. A partir del Capítulo II se exponen las actividades de los piratas, contrabandistas y bandidos y su impacto en la América colonial española. El capítulo III aborda el accionar de los grupos de crimen organizado y la amenaza que estos suponen a los Estados nacionales del área. Finalmente en el Capítulo IV se comparan las actividades de unos y otros bajo el prisma de la mentalidad burguesa y se exponen las reflexiones que el estudio ha generado.

\section{La mentalidad burguesa}

José Luis Romero (1999, pp. 12,14 y 17) define el campo de las mentalidades como

“[... el el caudal de ideas que en cada campo constituye el patrimonio común y del cual aquél es como una especie de espuma, en relación no siempre coherente. La mentalidad es algo así como el motor de las actitudes [...] es "[...] un sistema "[...] de opiniones que abarca todos los campos posibles y que espontanea o sistemáticamente se transforma en respuestas acerca de las más diversas interrogantes [...] son ideas de una época, de un tiempo, de un período y que conjuntamente conforman una red muy complicada".

Las mentalidades también han sido caracterizadas como formas de pensar y sentir más emocionales que racionales y que proveen maneras no codificadas de reaccionar ante diferentes situaciones. Se les ha diferenciado 
de la ideología en el sentido de que la mentalidad es subjetiva, mientras que la ideología es objetiva. La mentalidad es actitud intelectual, la ideología contenido intelectual; la mentalidad es predisposición psíquica, la ideología implica reflexión y auto interpretación. La ideología es un concepto de la sociología de la cultura, la mentalidad es un concepto del estudio del carácter social (Geiger en Linz, 2000).

A pesar de lo señalado, para Romero (1999, p.45) la mentalidad burguesa implica una ideología en sentido estricto, y procede a definir el término de la siguiente forma:

"[... ] una ideología es un sistema de ideas al que se asigna valor de verdad absoluta y además un sentido progresivo o proyectivo; una interpretación de la que se deriva un encadenamiento tal que el futuro parece desprenderse del presente"; para él "[... ] una ideología expresa, describe un proceso histórico, e induce de esa descripción la continuación lógica, necesaria, forzosa, coherente".

La mentalidad burguesa es, según el autor citado, el meollo, la médula de la cultura occidental; es producto de un proceso de larga duración, de aproximadamente siete $u$ ocho siglos, el cual se divide en tres etapas. La etapa originaria data desde el siglo XI y se prolonga hasta el siglo XIV. En este período casi no hay una mentalidad burguesa sino que adopta los aires de ésta cuando se reflexiona sobre sus contenidos, sus supuestos y fundamentos. Es la fase de la acción espontánea y la experiencia en la cual aparecen opiniones que comprometen el orden tradicional que lidian con la mentalidad cristiano feudal prevaleciente; se reflexiona sobre las nuevas formas de vida económica y colectiva que gravitan alrededor de las ciudades. La siguiente etapa la constituye la revolución ideológica del siglo XVIII, resultado de procesos sociales que se suscitan entre los siglos XIV y XVIII, en que las aristocracias y burguesías ${ }^{2}$ pasan de ser urbanas a nacionales, transformándose en instrumentos del Estado moderno. El conocimiento científico se desarrolla notablemente con su consiguiente impacto en la esfera de las ideas sociales y religiosas; la naturaleza se hipostasia ${ }^{3}$ y adquiere existencia propia; es regido por sus propias leyes y gobierna el mundo profano. El último período es el de su consolidación y anidamiento, en el cual ya se ha configurado un sistema de ideas tan coherente que expresa una clara concepción del mundo y se constituye

2. Estamento que se va a formar durante los siglos $\mathrm{X}$ y XI a partir del establecimiento de mercaderes y artesanos en torno a los "burgos" o recintos fortificados, representando un tipo de vida y ser nuevos, no sometidos al vínculo señorial o a servidumbre (García, Luis y Carrande, Ramón, 1960),

3. Relativo a la hipóstasis, que significa según el diccionario en línea de la RAE: "supuesto o persona, especialmente de la Santísima Trinidad". En este caso se usa para referirse a una cualidad ontológica del objeto. 
en la base del pensamiento progresista del Siglo XIX y XX. La mentalidad burguesa es adoptada por las burguesías cultas y se transforma en un modelo para los altos niveles de las clases medias que pugnan por acercarse a aquellas. Las experiencias básicas que nacieron de nuevas situaciones sociales y económicas, se han racionalizado hasta alcanzar su apogeo y constituirse en un esquema de ideas básicas y un sistema de criterios para entender la realidad (Romero, 1999).

La mejor forma de distinguir la mentalidad burguesa de otras mentalidades es comparándola con la que sustituyó —el sistema de ideas de la tradición cristiano feudal-. Para la mentalidad cristiano feudal el mundo es de corte tradicionalista, señorial y rural; la sociedad constituye un orden fijo y preestablecido en el cual la movilidad social es nula; la principal actividad económica es la agrícola y se tiene una concepción estática de la historia. Prevalece el providencialismo, según el cual el ser humano solo cumple lo que ya está escrito y los hechos humanos solo son la realización del plan divino y la voluntad de Dios. La realidad se interpreta como sagrada y se asocia lo real con lo irreal. Lo único que se considera real es lo inteligible, lo que se puede expresar en conceptos. La relación con la naturaleza se caracteriza por el desconocimiento del mundo circundante lo que propicia el surgimiento del misterio y todo lo extraño deviene en sobrenatural. Prevalece la concepción teológica en la cual resulta más importante el "estar" que el "andar". Lo fundamental en la persona es el condicionamiento social y el mundo se divide en privilegiados y no privilegiados, en personas libres y no libres - un principio de dependencia y jerarquía sujeta a la persona y lo más importante no es el individuo, sino el cuerpo social, la comunidad-. El fundamento de todo es religioso y el poder tiene un origen divino. La ética reposa sobre la verdad revelada y la moral tiene un fundamento dogmático. Consecuentemente, la norma es dogmática, inmutable y ahistórica. La máxima virtud es la devoción y no hay una metafísica sino una teología, en la cual todo lo allende a lo sensible es Dios. En síntesis la divinidad domina el mundo (Romero, 1999).

A contrario, la mentalidad burguesa se arraiga en el mundo urbano. La ciudad deviene en lo activo, el fermento operativo para difundir las formas de vida e ideas que la burguesía había venido elaborando. La sociedad se entiende como un orden dinámico generado por el ser humano en el cual la movilidad social es posible. Así mismo se tiene una concepción dinámica de la historia, cuya característica principal es el progreso, entendido como una marcha cualitativa en que cada etapa es superior a la anterior y el cual se manifiesta en el campo del avance de la civilización y en el dominio de la naturaleza por el hombre por medio de la técnica. La "marcha” es más importante que la "llegada". 
En la concepción burguesa la realidad deviene en profana y se da una disociación entre realidad e irrealidad. También opera una doble disolución la del ser humano y la naturaleza, y la de la realidad y la realidad sobrenatural. La realidad es cognoscible, de tipo natural o sensible. El conocimiento es controlado por un aparato metodológico y epistemológico. Consecuentemente, el ser humano se transforma en sujeto cognoscible y la naturaleza en objeto de conocimiento. Éste descubre la variedad y diversidad de la naturaleza y descifra que ésta constituye un orden, con características observables y sistematizables. La naturaleza funciona de una manera coherente en la cual a idénticas causas sobrevienen idénticos efectos. La naturaleza es la realidad sobre la cual el ser humano puede operar para obtener beneficios. La pregunta filosófica fundamental es sobre la naturaleza y sobretodo como se le conoce, surge la teoría del conocimiento. También aparece la metafísica en un intento para explicar lo que está más allá de la realidad sensible.

El poder político tiene su origen en el pacto social. La sociedad y las formas de vida urbana requieren de normas que la regulen, que surjan de la convivencia. El poder se torna profano y la moral se seculariza nace del vínculo entre las personas y su fundamento es el consentimiento del grupo social. El máximo mérito es el trabajo y éste y la riqueza se constituyen en las máximas virtudes.

Para la mentalidad burguesa la principal actividad económica es la mercantil e industrial y predomina la economía de mercado. El sistema de producción se organiza para atender un mercado dinámico en el cual la oferta, la demanda y el precio se constituyen en sus leyes fundamentales. El dinero se atesora y la acumulación de riqueza permite a la persona iniciarse en la aventura económica. El éxito económico propicia el ascenso social.

La persona es concebida como individual e independiente con capacidad para correr con cierta aventura y hacer su vida. Lo importante es el individuo, no el grupo social, quién vive desprendiéndose de los vínculos de dependencia. La persona es hija y dueña de sus obras, es un ente de razón y voluntad que vive como quiere, hace lo que quiere y la historia deviene en el resultado de sus pensamientos y acciones; vive para probar la plena racionalidad y la razón domina al mundo.

En la mentalidad burguesa se advierte una actitud básica inicial, la racionalización, la búsqueda de causas y efectos, el conocimiento basado en la experiencia. La primera gran conquista se alcanza con lo que Romero 
denomina "el triunfo de la profanidad". Este término define el entendimiento del ser humano con el mundo inmediato como realidad última, sin preguntarse qué hay allende a él. La realidad se delimita en operativa, aquella cuyo comportamiento puede preverse en términos adecuados para la acción.

Como se ha señalado, la naturaleza puede ser conocida a través del conocimiento, ella constituye un orden del cual solo es necesario descifrar las leyes que la rigen, para ser dominada por la técnica. En lo que respecta a la imagen de la persona, primero se antepone el individuo al conglomerado social. El individuo se lanza a la aventura del ascenso socio-económico. No existen barreras para aquel que está dispuesto a esforzarse, la imagen de triunfador deviene en el mercader y se valora la picardía y la astucia.

La persona es un individuo independiente del grupo, que corre con la aventura de su propia vida. Entre individuos libres sobreviene la idea del contrato como base de legitimidad política y el poder también se torna profano. La economía de mercado tiene un profundo impacto en la mentalidad burguesa. El ascenso económico implica el ascenso social, todo tiene su precio determinado por las leyes de la oferta y la demanda. El intercambio de bienes se lleva a cabo en moneda lo que a su vez conlleva a su atesoramiento, la acumulación y concentración de la riqueza se da en las ciudades, seno de la mentalidad burguesa.

El poder político tiene una tremenda incidencia en la economía; aquel que detenta el primero, reconoce que su riqueza está en la expoliación de los comerciantes en las ciudades, él puede favorecer o entorpecer la actividad mercantil. El Fisco toma gran relevancia y el poder de los Estados se considera que está ligado a su capacidad de acumular metálico. El sistema se basa en una dinámica combinación de liberalismo, republicanismo y democracia.

Lo propio del burgués es gozar la vida, alcanzar la gloria y la fortuna. La regla inquebrantable de las relaciones de dinero es la palabra empeñada y el pago de sus deudas. El régimen normativo surge de la convivencia; la moraldel trabajo y la moral de la riqueza constituyen la nueva moral burguesa. La riqueza es la virtud suprema, el hombre deviene en hijo y dueño de sus obras. Es un ser profano, natural sujeto de instintos y pasiones, ente de razón y voluntad. Vive como quiere, hace lo que quiere y su albedrío es ilimitado. El consumo es el rey, y las masas que se incorporan a él se apoderan del sistema de ideas vigente en las clases medias, las cuales a su vez emulan a las clases altas por ser un signo 
de status. Resumiendo las ideas básicas de la mentalidad burguesa se sintetizan en el sujeto, la razón y el progreso (Romero, 1999).

El advenimiento del movimiento del romanticismo, rechazo de la locura Napoleónica, y la revolución industrial, con su avocación por el retorno al pasado, la disidencia e inconformismo de la bohemia, la aparición del fascismo, el comunismo, la dialéctica de la llustración, la bipolaridad, el Tercer Mundo, auguran la crisis de la mentalidad burguesa. Esta última, sin embargo, va a tener un respiro, un nuevo aire con el acaecimiento, a finales del siglo XX, del neoliberalismo. El "yuppi", la voraz ambición de los "extorsionistas verdes" " y la ola de adquisiciones corporativas hostiles, bajo el mote "la ambición es buena" van a devenir en los nuevos piratas ("corporate raiders") y otra vez la mentalidad burguesa va a estar en boga. Este tipo de ambición, no podría ser más que alimentado por un insaciable amor al dinero. El estar pendiente de los mercados mundiales en los cuales unos cerraban al momento que abrían los otros; las exigencias del trabajo, solo podían ser soportadas bajo una completa adición a la cocaína y la metanfetamina, situación que a la vez propicia la articulación de los grupos de crimen organizado para la provisión de las drogas a un mercado inagotable. Las sobras de las drogas de las élites profesionales se canalizan a los guetos y villas miseria en la forma malévola de "crack". Este tipo de locura no podría tener otro final que el descalabro trillonario y desenmascaramiento de la falacia neoliberal de la crisis económica de 2007.

\section{Piratas, contrabandistas y bandidos: su impacto en la América colonial}

El descubrimiento de América crea indudablemente una serie de cambios políticos, económicos, sociales y culturales. La expansión geográfica y política que genera, contribuye significativamente a formar una imagen del mundo radicalmente diferente y a la consolidación de la mentalidad burguesa. "Es el mundo burgués y urbano que coloniza América, fundando ciudades a su propio modelo" (Romero, 1999, p.1). Las ciudades en la América colonial eran los centros de concentración de poder desde donde se reproducía el modo de vida europeo, se dirigía el proceso económico y se trazaba el perfil de los territorios en que se ejercía su influencia. A cada una de estas urbes se le había comisionado una función específica dentro

4. "Greenmailers". Chantaje financiero, práctica financiera común en la década de los 80, por medio de la cual inversionistas sin escrúpulos, iniciaban la compra hostil de una compañía con el fin de que ésta comprara de regreso las acciones para evitar ser "tomada". 
del sistema colonial: ya fuese puerto, reducto militar, centro minero o de emporio comercial.

El mercado se constituía en el núcleo fundamental de las ciudades, lugar donde se concentraba y circulaba la riqueza y cuya condición determinaba la prosperidad de las mismas (Romero, 2001). En un nuevo mundo tan bello como inhóspito, tan exuberante como misterioso, tales joyas ${ }^{5}$ no podían dejar de atraer por mucho tiempo, a aquellos que buscaban el enriquecimiento pronto y fácil, con su apego a la apropiación de lo ajeno y el uso de todo tipo de medios para saciar su enorme ansia de riqueza: los piratas, los contrabandistas y bandidos. No es de extrañar entonces, que la principal preocupación de las ciudades estuviera relacionada con el mantenimiento de su seguridad. Éstas no estaban equivocadas, los piratas, contrabandistas y bandidos contribuyeron de sobremanera en el declive del imperio español en América. Estos actores ilegales se distinguían entre sí por el tipo de actividades ilícitas a que se dedicaban: los piratas se enfocaban en el ataque a naves, asentamientos y ciudades con el fin de apropiarse de las riquezas que los españoles extraían de su colonia americana; los contrabandistas se concentraban, operando tanto en tierra como en el mar, en burlar las autoridades y controles fiscales para proveer bienes libres de tasas impositivas a la América española y finalmente los bandidos se dedicaban al robo y asalto de todo tipo de víctimas en tierra.

Irónicamente el surgimiento de este tipo de "lacras" fue propiciado por la propia política española. La decisión de optar por un sistema mercantilista, en que el éxito económico del país se basaba en su habilidad para acumular riqueza, sobretodo en lingotes de oro y plata, así como la intención de asegurar mercados para la obtención de materias primas y venta de sus manufacturas, requería de la implantación de un severo control administrativo y la imposición del monopolio estatal. También implicaba el evitar las pérdidas comerciales por la actividad de piratas y contrabandistas, fomentada por las otras potencias europeas, cuya codicia fue despertada por el despliegue de las riquezas americanas e indudablemente querían participar en la repartición del tesoro y en romper el monopolio impuesto por España.

Fundamentalmente, la base del mercantilismo radicaba en el control de la economía con el fin de promover los intereses nacionales. Su énfasis se

5. En el área Mesoamericana y El Caribe, La Habana, Cartagena, Portobelo y Veracruz eran los principales puertos por donde fluía el comercio hispanoamericano, su ocupación y saqueo era añorada por los piratas. 
centraba en la consolidación de la riqueza colectiva. Su innovación radicaba en el traslado del centro de control del nivel local al nivel nacional, lo que conllevaba la regulación del comercio favoreciendo la producción local, la acumulación de metales preciosos, y las políticas proteccionistas del comercio destinadas a fomentar armadas fuertes. Mientras que la política comercial se podría hacer a nivel nacional para promover los intereses nacionales; las instituciones para hacer cumplir éstas, a nivel nacional, no se habían desarrollado todavía, situación que motivó que dicha regulación se llevará a cabo por quienes tradicionalmente habían ejercido esa función en el ámbito local: los gremios de mercaderes (Nachbar, 2005).

En el caso de España dicha función se le encomendó, desde 1503, a la Casa de Contratación de Sevilla, la cual estaba a cargo de la administración y control de todo el tráfico hacia la América española. El mercantilismo también sostenía que la fuerza económica de un país estaba directamente relacionada con el mantenimiento de un saldo positivo del comercio. Un país para ser económica y políticamente viable debe exportar más de lo que importa. Dicho saldo positivo del comercio permite al Estado lograr acumular oro en sus arcas acrecentando su poder nacional. Cinco son los elementos que permiten esta acumulación de riqueza: 1) El nacionalismo y la política se complementan: toda la política se dirige hacia el engrandecimiento de la nación; 2) El comercio exterior siempre debe visualizarse en términos de su efecto sobre sus reservas de metales preciosos; 3) Ante la falta de minas de oro o plata nacionales, estos metales preciosos deben acumularse a través del logro de un superávit de las exportaciones sobre las importaciones o de la explotación de minas en sus colonias; 4) El gobierno debe de limitar las importaciones y fomentar las exportaciones y; 5) Tanto la política económica interior como la política exterior del Estado deben ser coordinadas hacia el logro de estos fines (Sills, 1968). 
Gráfico 1.

Las exportaciones americanas (1543-1660)

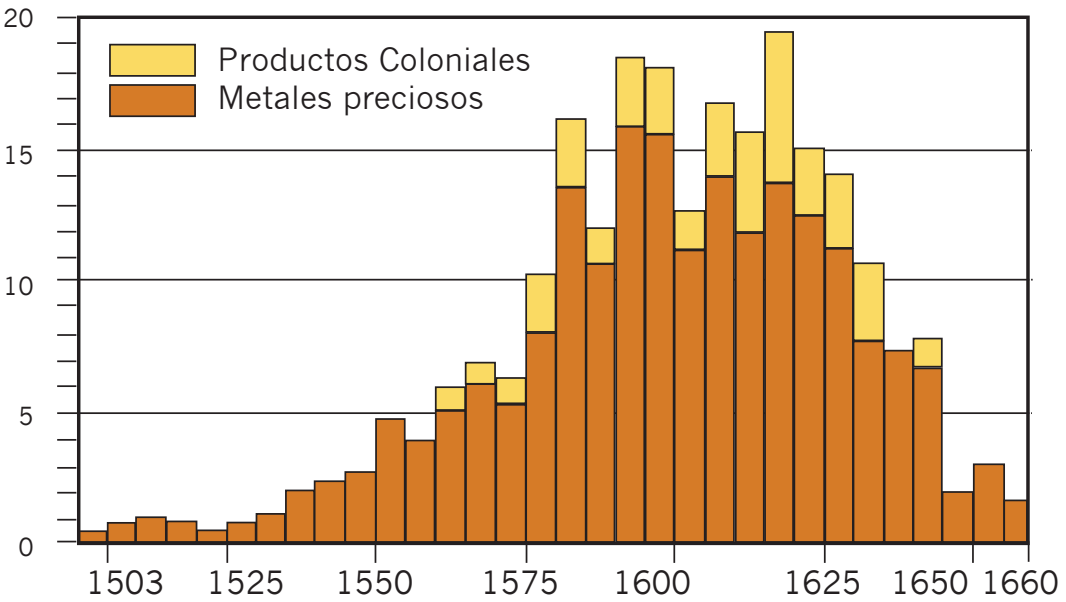

Fuente: http://www.gabrielbernat.es/colonia/mineria/index.html

\begin{abstract}
Enel gráfico 1 sepuedenapreciar los efectos de laaplicación del mercantilismo en el comercio entre las colonias y la metrópolis española. El mercantilismo español resultó al final, no solo poco práctico económicamente sino que era imposible de implementar administrativamente. Los gobernadores españoles se enfrentaban con dos tipos de impedimentos: uno de carácter natural, constituido por las características propias de las extensas costas y territorio americano, en el cual solo se tenía, si acaso, escaso control; y el otro de carácter administrativo, sobre el cual los funcionarios reales tenían una mayor incidencia, sin embargo, no eran menos infranqueables que los naturales. Estos últimos se potenciaban por la venalidad, incompetencia e ineficiencia de muchas de las autoridades administrativas. Situación claramente señalada por Schaefer:
\end{abstract}

\begin{abstract}
"La ignorancia y la ineficacia de los funcionarios es una de las continuas quejas de virreyes y visitadores reales. Sumado a factores como la corrupción, que propiciaba por igual las bajas remuneraciones, la inexistencia del espíritu de servicio y la escasa preparación, que a veces llegaba hasta la falta de saber leer y escribir, constituyeron los varios motivos de la ineficiencia de la administración colonial" (Schaefer en Fajardo, 2002).
\end{abstract}

También era preocupante, en la administración colonial, la escasez de recursos de todo tipo para enfrentar la amenaza; inclusive se recurrió por 
parte de las autoridades administrativas a concesionar los servicios de seguridad de la zona a empresas privadas. Asimismo, la ausencia de la implementación de medidas y acciones coordinadas entre las diversas autoridades administrativas para prevenir el contrabando, contribuía sobradamente en la ineficacia para controlar el problema (Sanders, 1977).

Cuadro 1.

Envíos de oro y plata a España en el siglo XVI, en valores absolutos

\begin{tabular}{|c|r|r|}
\hline Años & Oro (kilos) & Plata (kilos) \\
\hline $\mathbf{1 5 0 3 - 1 5 1 0}$ & 4.965 & 0 \\
\hline $\mathbf{1 5 1 1 - 1 5 2 0}$ & 9.153 & 0 \\
\hline $\mathbf{1 5 2 1 - 1 5 3 0}$ & 4.889 & 148 \\
\hline $\mathbf{1 5 3 1 - 1 5 4 0}$ & 14.466 & 86.193 \\
\hline $\mathbf{1 5 4 1 - 1 5 5 0}$ & 24.957 & 177.573 \\
\hline $\mathbf{1 5 5 1 - 1 5 6 0}$ & 42.620 & 303.121 \\
\hline $\mathbf{1 5 6 1 - 1 5 7 0}$ & 11.530 & 942.858 \\
\hline $\mathbf{1 5 7 1 - 1 5 8 0}$ & 9.429 & 1.118 .592 \\
\hline $\mathbf{1 5 8 1 - 1 5 9 0}$ & 12.101 & 2.103 .027 \\
\hline $\mathbf{1 5 9 1 - 1 6 0 0}$ & 19.451 & 2.707 .626 \\
\hline
\end{tabular}

Fuente: http://www.gabrielbernat.es/colonia/mineria/index.html

En el contexto colonial hispanoamericano, la región Mesoamericana y El Caribe tomó una inmensa relevancia, dado que se constituía en el espacio geográfico por donde se canalizaba todo su comercio. El istmo de Panamá era una de las más importantes regiones del Nuevo Mundo para España, su nivel de importancia solo estaba detrás de México y Perú. Para la navegación comercial entre España y sus colonias durante los siglos XVI y XVII, el puerto de Portobelo en Panamá se convirtió en el centro económico regional, el lugar donde se llevaba a cabo la mayor de las ferias comerciales de América (Ward, 1988). A manera de ejemplo en el cuadro 1 se presentan los envíos de oro y plata desde las colonias americanas hacia España. Obviamente, también en esta área se iba a asentar la actividad de piratas y contrabandistas, siendo sus bases de actividad o guaridas las infames localidades de Port Royal en Jamaica y la isla Tortuga al nordeste de la República Dominicana (Zahedieh, 1986). 


\subsection{La piratería}

Los piratas ${ }^{6}$ fueron la respuesta tardía de las otras potencias europeas a la expansión imperial española. La piratería era fomentada para debilitar el poderío español alimentado por las inmensas riquezas que provenían de sus posesiones americanas; sin embargo, la piratería creció incontrolablemente, hasta constituirse en una amenaza a las mismas potencias que la azuzaron (Fuchs, 2000). En su apogeo los piratas del Caribe empleaban 2 mil 400 hombres y disponían de 25 a 30 navíos. El capitán de piratas más exitoso, Bartholomew Roberts, o "Negro Bart", se decía había saqueado 400 barcos (Boot, 2009).

La amenaza de los piratas al comercio entre la metrópolis española y sus colonias y la búsqueda de éstos de la oportunidad para saquear y apoderarse de las ciudades, generó que a través del área emergiese la ciudad-fuerte, custodiada por impresionantes fortalezas, morros y murallas, tan imponentes como inefectivas, que protegían a la ciudad civil (ver mapa 1).

Esta práctica feudal de encerrarse tras muros, es el inicio del surgimiento de una "arquitectura de miedo" vigente hasta nuestra época, la cual fragmenta el espacio público, engendrando nuevas formas de segregación espacial e discriminación social (Romero, 2001; Jütersonke, Muggah \& Rodgers, 2009). Otro efecto social que la piratería tuvo en la América española fue que ante los repetidos asaltos a sus posesiones y a la escasez de españoles, las autoridades coloniales administrativas y militares, ante su temor de armar a las mayorías indígenas (de por sí otra preocupación de seguridad), recurrieron a armar a una pequeña pero cada vez más creciente minoría de orígenes africanos, conocidas como "milicias Pardos" (Lokken, 2004).

6. Los piratas eran motivados por su afán de lucro, trabajaban por cuenta propia, el bucanero (co. nocido por su afición a cocinar carne asada "bucan") y el filibustero eran los piratas que operaban en América y los últimos (filibusteros) exclusivamente en el área del Mar Caribe. Los Corsarios eran aquellos que tenían un corso o sea una patente concedida por algún gobierno que le permitía atacar las naves españolas, su afán era causar pérdidas al enemigo y afectar sus posesiones. 


\section{Mapa 1.}

\section{Fortificaciones españolas primarias y secundarias en área Mesoamericana y El Caribe}

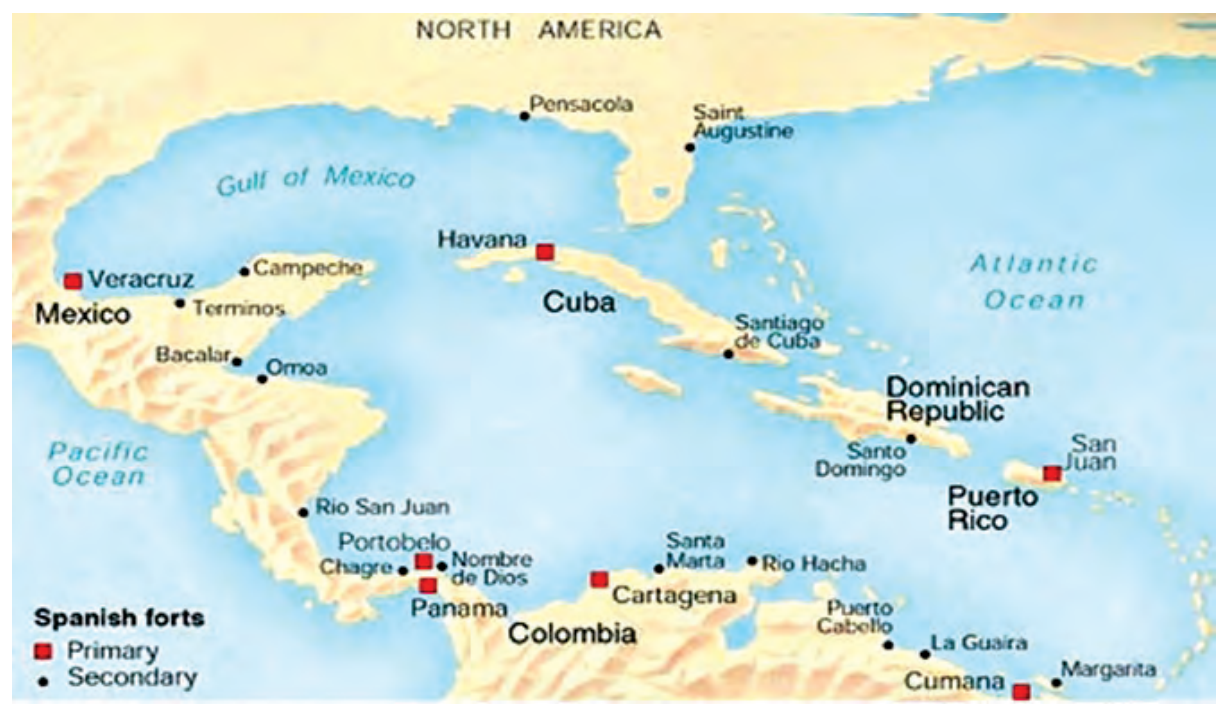

Fuente: http://www.nps.gov/hr/twhp/wwwlps/lessons/60sanjuan/60locate1.htm

Para el transporte y protección de los tesoros americanos se comisionó a la Armada y Flota de Tierra Firme y a la Armada de la Guarda de la Carrera de las Indias, las cuales consistían en convoyes de embarcaciones comerciales que eran custodiados por galeones de guerra, que periódicamente hacían el peligroso trayecto de América hacia España y viceversa. Además, basada en Veracruz se destacó la Armada de Barlovento, encargada de limpiar las aguas del Caribe de piratas e impedir el tráfico comercial ilegal. También se comisionó a la Armada del Mar del Sur el preservar los contactos entre el Virreinato peruano y el istmo y asegurar los caudales que se giraban a Panamá. El principal barco de combate de estas armadas lo constituían los galeones con una capacidad artillera de 55 a 80 cañones y desplazaban entre 500 y 1,600 toneladas. A manera de ejemplo, los galeones de escolta de la Carrera de Indias a mediados del siglo VXII Ilevaban entre 26 y 46 cañones y, para finales de ese siglo navegaban armados con 40 a 50 piezas de artillería (De Pazzis Pi Corrales, 2001). El presupuesto del mantenimiento de la Armada de Barlovento alcanzó la cantidad de 600 mil pesos anuales: las Reales cajas de México contribuían con 200 mil pesos y; las de Yucatán y Guatemala aportaban 40 mil pesos cada una. El número de los navíos que la conformaba era de doce galeones y dos 
buques pequeños, pero esa cantidad fluctuó mucho a través del siglo XVII, siendo regularmente la mitad de ese número (Rubio Mañe, 1983).

\subsection{Los contrabandistas}

Paralelo al comercio legal se propagó un comercio ilegal, cuyo volumen sobrepasó en importancia al primero. Los funcionarios reales en las Indias se encontraron que el contrabando era uno de los más críticos y apremiantes problemas de la administración colonial. Éste existió durante todo el período colonial, a pesar de los vigorosos esfuerzos por eliminarlo, su expansión se debió a una muy buena razón, era una práctica sumamente lucrativa (Sanders, 1977; Pijning, 2001). El círculo vicioso que generaban sus inmensas ganancias era tan predecible como antiguo, su base, las leyes del mercado: a mayor prohibición de un bien codiciado, mayor su precio, mayores las ganancias que genera. Esta situación propicio el surgimiento de una nueva casta de comerciantes: Ios contrabandistas, quienes estaban decididos a acelerar el progreso de su enriquecimiento, sin preocupaciones accesorias de carácter social. La relación beneficio-inversión de participar en el contrabando era tan elevada que los individuos estaban dispuestos a correr grandes riesgos que más frecuentemente que no, resultaban en la creación de grandes fortunas personales (Romero, 2001; Ward, 1998).

El contrabando era muy importante en la América colonial y a partir de éste las élites americanas pudieron construir su poder, el cual en el futuro sería determinante para hacerse valer ante las exigencias españolas. España no tenía capacidad para responder a las demandas comerciales de los americanos, vacío que se encargarían las potencias europeas de llenar, las cuales vieron mejoradas su posición en el mundo, no solo por esto, sino porque mientras España se concentraba en la obtención de oro y plata, los demás países europeos dedicaban sus esfuerzos a desarrollar su industria, lo cual les generaría mayores posibilidades en un futuro (Ventieri, 2010).

La participación en el contrabando redituaba inmensas ganancias para los criollos y era tolerado por la vasta mayoría de la población, porque resultaba enormemente beneficioso para todos los involucrados. Una sociedad como la colonial, con bien establecidas redes familiares, de compadrazgo y de amistad, era más propicia para encubrir el contrabando que para prevenirlo. También los enlaces entre las empresas formales y las informales servían para facilitar la introducción del alijo, ya que los barcos legales informaban sobre las condiciones de seguridad en los puertos y las costas a los contrabandistas, así como también facilitaban 
la canalización de las ganancias obtenidas por medios ilegales hacia la legalidad. En este sentido se articulaba un "imperio" reticular encubierto, anclado en economías clandestinas, que se traslapaba con la economía legal y constantemente se imponía a los programas fiscales y militares de la Corona. Ante esta extensa red de redes de organizaciones, no era de extrañar que ninguna de las medidas represivas impuestas para prevenir el contrabando: incremento de las patrullas de soldados, la imposición de la pena de muerte a aquellos que se dedicaban a dicha actividad, la construcción de fortalezas, la privatización de las patrullas costeras y el despliegue de la flota y armada, tuvieran mayor éxito. Además los métodos utilizados por los contrabandistas eran variados y flexibles y se adaptaban con relativa facilidad ante la aparición de circunstancias desfavorables o a la implementación de medidas orientadas a su erradicación (Sanders, 1977; Ward, 1998; Owens, 2005).

El contrabando también generó la aparición e institucionalización de la corrupción. El clero y los altos funcionarios de la administración colonial estaban involucrados en este comercio ilícito, su participación era un aspecto más que reflejaba la corrupción existente entre las élites y la nobleza colonial. Las riquezas que dicha actividad les producía les permitían gozar de una mayor autonomía del poder de la metrópolis. El alto volumen de mercancía contrabandeada implicaba que tanto los gobernadores como los funcionarios reales eran generalmente culpables de corrupción o de pasiva o activa convivencia con el contrabando o al menos de incompetencia o ineficiencia en prevenirlo.

Importante resulta destacar que los nativos de las diferentes zonas costeras facilitaban el contrabando, al tomar una parte activa en la actividad ilícita, sirviendo como espías, guías, guardias y escoltas de los contrabandistas, ya sea por su desprecio por el poder colonial o más comúnmente por su afán de lucro. A finales del siglo XVII era evidente que la Corona española había perdido control sobre el sistema mercantil que había implementado (Brown, 1928; Sanders, 1977; Ward, 1988; Owens, 2005).

\subsection{Los bandidos}

Las ciudades formales, planificadas de las fundaciones, con el correr del tiempo fueron develando las ciudades reales. En este sentido, cada una de las sociedades urbanas fue tomando conciencia de su propia especificidad, producto de su entorno y población, muy distinta de las ciudades españolas o de las otras urbes latinoamericanas. Dentro de estas ciudades, el hampa junto a asesinos y ladrones se movían alrededor 
del juego y la prostitución, dado que en ese mundo de vicio y hedonismo se aproximaban todas las clases y castas. En los alrededores de estas ciudades gravitaba una sociedad informal que se instalaba en jacales o bohíos, inestable y marginal, cuyos miembros subsistían transitando entre las actividades lícitas e ilícitas. También muchos de estos marginados conformaban grupos de bandoleros que emprendían sus acciones en los caminos, asaltando haciendas o apartadas aldeas, matando a todo aquél que se les resistía, se gestaba de esta forma un enfrentamiento entre la "sociedad establecida" y esta "sociedad rebelde". Eran los suburbios donde la delincuencia instauraba su baluarte, localidades donde el anonimato y la falta de curiosidad por los demás eran respetados. Desde estas guaridas, los delincuentes incursionaban al centro urbano para cometer sus fechorías (Romero, 2001).

Durante los últimos años de la Colonia y después de alcanzada la Independencia, en cuyas batallas pelearon muchos bandidos que se hicieron soldados y muchos soldados que después se hicieron bandidos y otros que siempre fueron bandidos y soldados, las ciudades eran a su vez, los centros del poder político como también el núcleo de los motines cuarteleros o de las movilizaciones populares. Estas crisis de poder y la prevalencia del bandidaje, obligaban a cada señor o hacendado a organizar su propia defensa, armando a sus hombres y convirtiendo sus casas en verdaderas fortalezas. De estos ejércitos privados muchas veces se desprendían bandas para trabajar por su cuenta en operaciones de pillaje.

Las guerras y la anarquía brindaban a los bandidos la oportunidad de buscar su sustento y acaso su riqueza, mediante el crimen y el robo. También no era raro que muchas de estas bandas de facinerosos gozaran de la protección de grupos más influyentes que participaban de sus ganancias, unos y otros eran alentados por sus ansias de alcanzar el modo de vida de los estratos de la alta sociedad. El legado más infortunado del bandidaje fue la transmutación de civiles en militares y la práctica del ejercicio del poder arbitrario por medio de la fuerza y la violencia (Romero, 2001).

\section{El crimen organizado: amenaza a la vigencia de los estados nacionales}

El fin que persigue el crimen organizado que no es otro que asociarse y organizarse en búsqueda del lucro, objetivo que no se detendrá ante nada ni nadie para ser alcanzado. Definiciones de crimen organizado hay tantas como tantas normativas existen en el mundo, debido a que cada país trata de enmarcar en su definición las características propias 
que este fenómeno tiene en su realidad. Como bien lo ha señalado la National Criminal Intelligence System, el organismo de contacto de las policías británicas, "es más fácil discutir sobre el crimen organizado que definirlo [...] Sabemos lo que es pero es complicado describirlo"7. Dos elementos si están presentes en todas las definiciones de las organizaciones de crimen organizado: 1) Que están conformados por dos o más personas que conspiran constante y conjuntamente y, 2) Que su asociación se debe al fin de cometer delitos para obtener beneficios.

Otro aspecto obvio es que las organizaciones que resultan más peligrosas para los Estados son aquellas cuya actividad criminal se extiende y viola las fronteras y leyes de varios países: las organizaciones de crimen organizado transnacional (UNDOC, 2002). ¿Qué factores han incidido en el surgimiento y propagación de este tipo de organizaciones?

Existen varios factores que están incidiendo, en la actualidad, en la reproducción y propagación de las organizaciones criminales de carácter transnacional, sobre todo en el área Mesoamericana y El Caribe. Entre ellas podemos señalar: el proceso de globalización, su situación geográfica que la torna en punto idóneo para la realización de todo tipo de tráfico de narcóticos, de personas, de armas pequeñas y livianas, y las condicionantes de tipo político, social-cultural y económicas que fomentan este flagelo.

\subsection{La globalización}

En términos económicos podemos definir la globalización como la interdependencia económica creciente del conjunto de países del mundo, provocada por el aumento del volumen y la variedad de las transacciones de bienes y servicios, así como los flujos internacionales de capitales y la difusión acelerada y generalizada de la tecnología.

En el ámbito cultural, la globalización se orienta hacia la homogenización, prevalencia y difusión de la cultura y valores estadounidenses; y en el ámbito humano se le responsabiliza de generar la miseria de las clases, países y regiones más pobres y, de haber dado lugar a una gran cantidad de flujos poblacionales (Sobrevilla, 2006).

Asimismo, la globalización y la creciente interdependencia económica han alentado y promovido la transformación del crimen:

7. Nestares, Carlos Resa. Crimen Organizado Transnacional: Definición, Causas y Consecuencias. http://www.uam.es/personal pdi/economicas/cresa//text11.html, consultado el 13.01.2013. 
a. Ha incrementado los efectos de la violencia en la organización del espacio físico y social.

b. La liberación económica y del comercio ha permitido que las organizaciones criminales (a partir de este momento se identificarán con las siglas OC) expandan sus redes y negocios ilícitos fuera de las fronteras nacionales, posicionándolas frente a nuevos mercados e incrementado su poder y riqueza, llegando inclusive a rivalizar y a sobrepasar los recursos de casi todos los Estados nacionales del Área Mesoamericana y El Caribe (ver gráfico 2).

c. La modernización de las telecomunicaciones y los sistemas de información ha facilitado a las OC sus transacciones internacionales, comunicaciones, coordinaciones, reclutamiento y entrenamiento.

d. El incremento de los flujos migratorios ha desdibujado las fronteras nacionales y ha favorecido el movimiento de las OC y brindado una multiplicidad de rutas para poder llegar a su destino. También ha debilitado a los Estados nacionales y ha permitido que las OC ingresen y ocupen espacios sociales y geográficos (UNDOC, 2002; Cuadra, 2003; Brennan-Galvin, 2002).

\section{Gráfico 2.}

Comparación del valor del mercado de cocaína en Estados Unidos en 2008, y los presupuestos nacionales de países centroamericanos 2012.

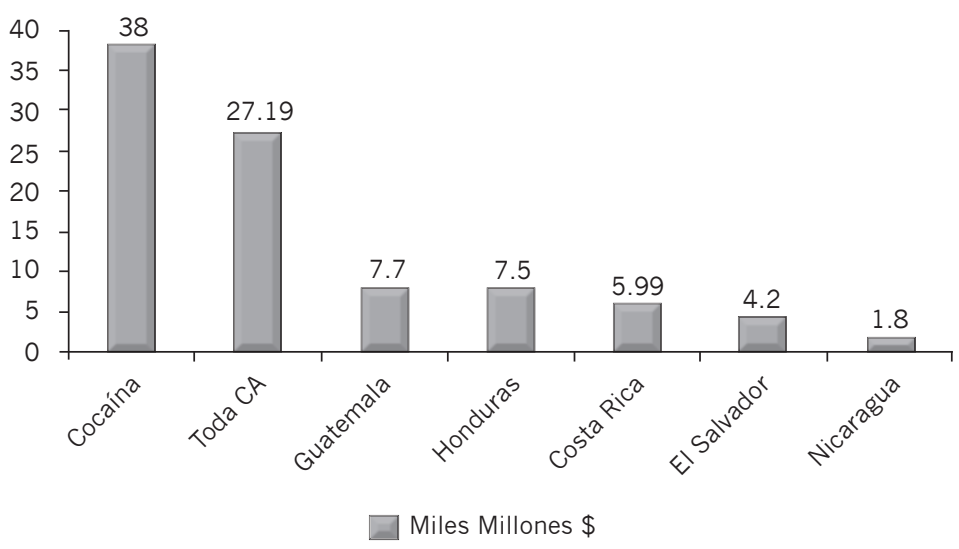

Fuente: Elaboración propia con datos UNODC Globalización of Crime Report 2010, presupuestos nacionales varias fuentes. 


\subsection{Situación geográfica}

El área Mesoamericana y El Caribe se encuentra ubicada en un lugar privilegiado de la esfera terráquea, como ya se señaló, se ha tornado de una bendición en una condena. Como en el tiempo de la Colonia, el área se configura en el centro del flujo de actividades lícitas e ilícitas entre los Estados fuente (que producen los bienes) y los Estados receptores de estos bienes. La metrópolis ha variado, de España ha girado hacia los Estados Unidos de Norteamérica (EEUU) sin embargo la importancia de la región para todo tipo de comercio se ha mantenido inmutable. A manera de ejemplo, solo por el canal de Panamá pasaron en el año 2011, 322 millones de toneladas de carga. ${ }^{8}$ También, por el mismo, durante ese año transitaron 12 mil 988 embarcaciones de diversos tipo (ver cuadro 2).

Cuadro 2.

Tráfico de naves por el canal de Panamá años fiscales 2011-2012 (número de tránsitos).

\begin{tabular}{|l|r|r|}
\hline \multicolumn{1}{|c|}{ Segmento de mercado } & \multicolumn{1}{c|}{$\mathbf{2 0 1 2}$} & \multicolumn{1}{c|}{$\mathbf{2 0 1 1}$} \\
\hline Porta-contenedores & 3,331 & 3,253 \\
\hline Graneleros secos & 3,339 & 3,285 \\
\hline Carga refrigerada & 1,116 & 1,479 \\
\hline Buques cisterna & 2,475 & 2,320 \\
\hline Carga general & 917 & 943 \\
\hline Porta-vehículos & 669 & 633 \\
\hline Otros & 804 & 850 \\
\hline Pasajeros & 211 & 225 \\
\hline Total & $\mathbf{1 2 , 8 6 2}$ & $\mathbf{1 2 , 9 8 8}$ \\
\hline
\end{tabular}

Fuente: micanaldepanama.com

Esta situación es ideal para fomentar la dinámica propia que generan las OC de carácter transnacional. En este dinamismo criminal, entre los Estado fuente y los Estados receptores, se encuentran una serie de Estados de tránsito y otra serie de Estados de servicio (donde las OC "lavan" sus ganancias). En estos último Estados (de tránsito y de servicio) las OC van dejando una estela de dinero el cual se va permeando en las economías locales generando inestabilidad política, corrupción, la disrupción de las leyes del mercado, pago de servicios legales (abogados, hoteles, transporte, servicios financieros, etc.), pago de servicios ilegales (sicariato, cobro de deudas, mercenarios, etc.). También se empiezan a conformar OC propias

8. AFP, 2012. Panamá espera más de 322 millones de carga en el Canal, sin cumplir la meta, http:// www.laestrella.com.pa/online/noticias/2012/04/19/panama-espera-mas-de-322-millones-de-carga-en el-canal-sin-cumplir-la-meta.asp, acceso 25 Octubre 2012. 
que emulan las prácticas de los grandes carteles y generan un ámbito de violencia al disputarse o proteger su territorio. En lo que se refiere al narcotráfico, se calcula que el tráfico global de drogas ilícitas genera una industria de entre 300 a 500 mil millones de dólares (Gootenberg, 2009). El 90\% de la cocaína que se dirige a los EEUU transita por la zona, convirtiéndola en la mayor región de tránsito en el mundo para esta droga (Stringham, 2009) (ver mapa 2).

\section{Mapa 2.}

\section{Tránsito marítimo de drogas a través del Caribe y Centroamérica} (2011).

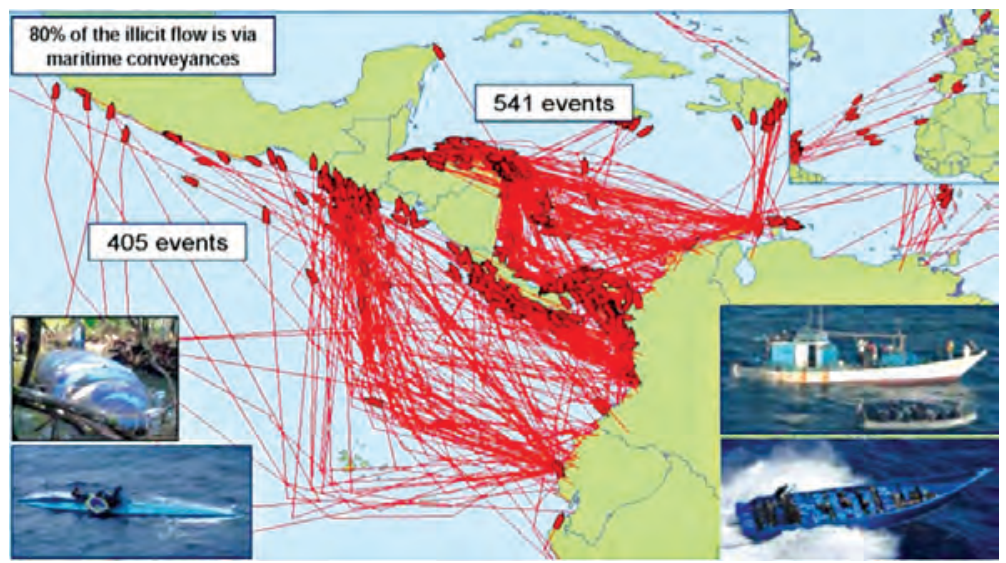

Fuente: Tomado de: "Preventing a security crisis In the Caribbean", http://www.feinstein.senate. gov/public/index.cfm/files/serve/?File id=90bb66bc-3371-4898-8415-fbfc31c0ed24.

La dimensión que el problema puede representar para los países del área se refleja en el dato que el valor de la venta global al detalle de cocaína es mayor que el producto nacional bruto de 123 de los 184 países que proveyeron este dato al Banco Mundial para los años 2007 y 2008 (UNODC, 2010, p. 69).

El tráfico y contrabando de personas es otro flagelo que es favorecido por la ubicación geográfica objeto de estudioº (ver mapa 3).

9. La diferencia entre tráfico y contrabando de personas radica en que el primero involucra la explo. tación del migrante; el segundo implica la procuración de la entrada ilegal a un Estado de un individuo que no es ciudadano o residente legal del mismo, a cambio de un beneficio material o financiero. INTERPOL. http://www.interpol.int/public/THB/PeopleSmuggling/Default.asp, consultado el 11.12.2012. 


\section{Mapa 3.}

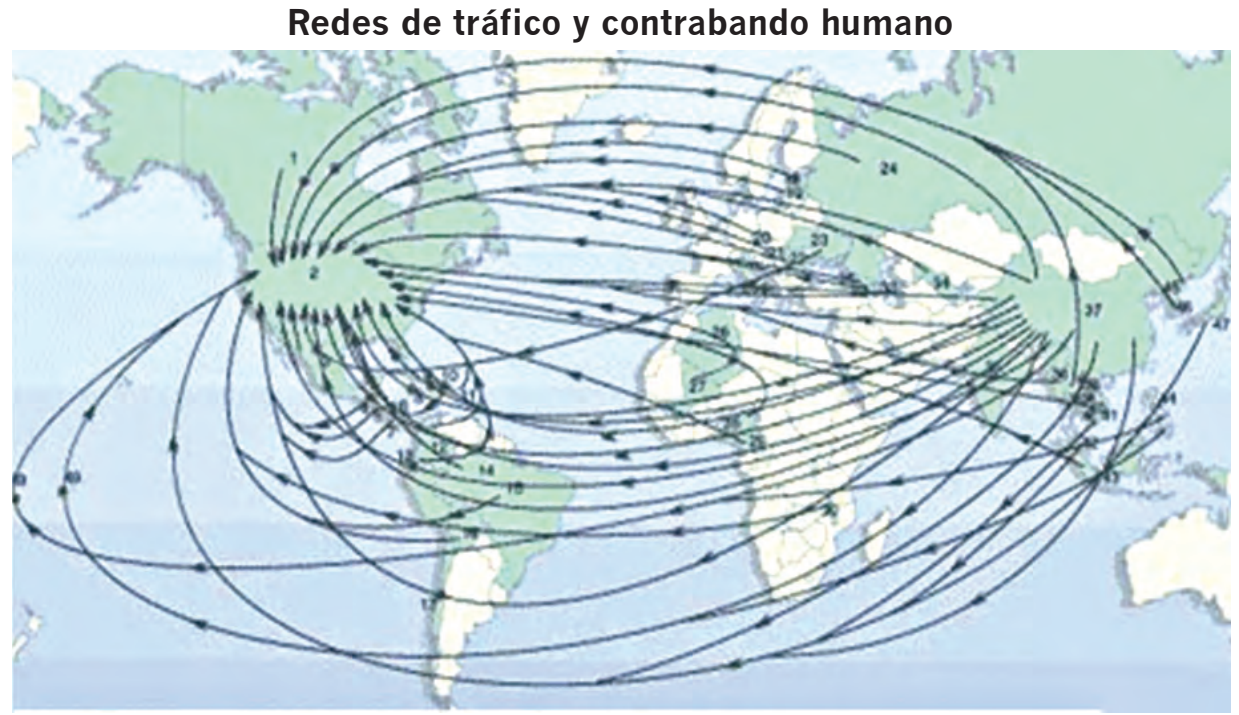

Fuente: http://tfgwebmaster.site.aplus.net/sitebuildercontent/sitebuilderpictures/us

Ante el hecho de que solamente en EEUU se calcula que habitan alrededor de casi 7 millones de migrantes mexicanos y centroamericanos ${ }^{10}$ los cuales envían a sus países de origen miles de millones de dólares en concepto de remesas, dinero que supera con creces las inversiones extranjeras y las ayudas gubernamentales (solo México en el 2003 recibió 13 mil 200 millones de dólares ${ }^{11}$ ) no es de extrañar que en el área existan redes sociales y criminales que facilitan la migración hacia el Norte, repartiéndose un negocio que se calcula supera los 10 mil millones de dólares ${ }^{12}$. Estas redes también fácilmente se pueden habilitar para ser utilizadas para el contrabando de otro tipo de bienes legales e ilegales.

En lo concerniente al tráfico de armas pequeñas y livianas, si consideramos que hay 649 millones de este tipo de armas ilegales en el mundo (Stohl \& Hogendoorn, 2010) podemos imaginar el impacto que esta actividad ilegal tiene en la seguridad de la diversas naciones (solo en El Salvador se calcula que existen 400 mil armas en manos de civiles $\left.{ }^{13}\right)$. Otro dato

10. Villela, Bernardo A. La Inmigración Centroamericana hacia los Estados Unidos de Norte América. http://ca2020.fiu.edu/Workshops/Salvador_Workshop/Bernardo_A_Villela.htm Once TV México. http:// oncetv-ipn.net/migrantes/mapas/stats2.htm, consultado el 11.12.2012.

11. http://www.revistafuturos.info/futuros 8/migrac silvia.htm, consultado el 11.12.2012.

12. Human Smuggling Fact Sheet, Royal Canadian Mounted Police Intelligence Directorate. October 2006. http://www.rcmp.grc.gc.ca/imm_pass/fact_human_smug_e.htm, consultado el 11.12.2013.

13. http://www.info7.com.mx/noticia. $p h p ? i d=139093 \&$ secc $=5 \&$ subsecc $=50$, consultado

el 11.12.2012. 
revelador del devastador impacto de la proliferación de armas, lo constituye el hecho, a manera de ejemplo, que el $81 \%$ y el $76 \%$ de todos los homicidios en Guatemala y El Salvador son cometidos con armas de fuego (Informe Sub-Regional Centroamérica y Panamá, 2006). Luego de exponer todas las circunstancias descritas no es de extrañar que la región esté incluida en el llamado "arco de inestabilidad" dentro del cual se llevan a cabo la mayor parte de conflictos y actos de violencia en el mundo (ver mapa 4).

\section{Mapa 4. \\ Arco de inestabilidad}

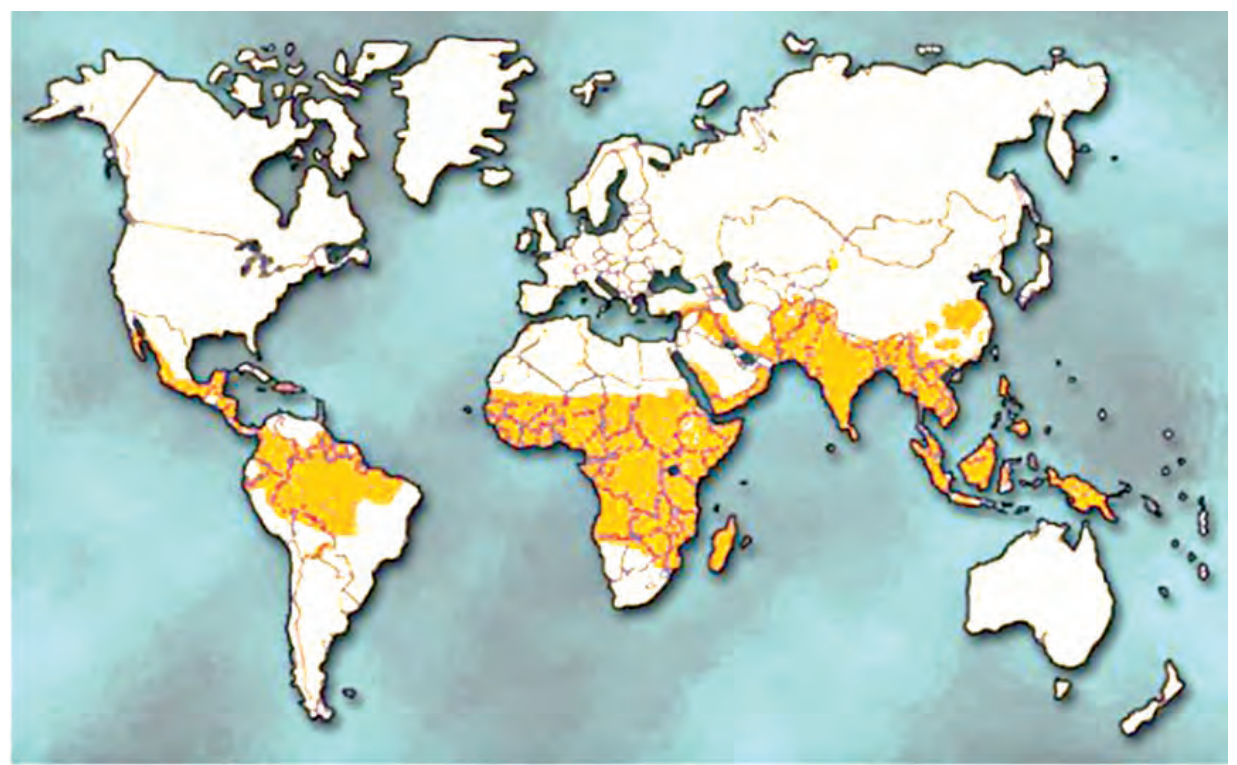

Fuente: BG Russ Howard. Conferencia Entorno de Amenazas, Programa de Asistencia para Combatir el Terrorismo, Miami, Florida, 18 de agosto de 2009.

\subsection{Condicionantes políticas}

Existen varias circunstancias políticas comunes en los países del área Mesoamericana y del Caribe que facilitan el surgimiento y la propagación de las OC, entre los cuales podemos señalar: la baja capacidad para satisfacer las crecientes demandas populares, el deterioro o estancamiento de algunas instituciones democráticas, la corrupción, la errónea y prevaleciente percepción de los Derechos Humanos como derechos que asisten al delincuente, una legislación inadecuada, un lento e ineficiente sistema judicial, y la fragmentación de los partidos políticos. También la baja capacidad coercitiva de los Estados reflejada en los altos niveles de 
impunidad existentes, señala una sensible deficiencia de las naciones en su función de proveer seguridad a la población.

El fracaso en proveer seguridad por parte del Estado es particularmente peligroso en las democracias incipientes de la región. Las personas con frecuencia interpretan que los elevados índices de crimen evidencian que las protecciones constitucionales han sido extendidas demasiado. Además la percepción de desorden puede provocar nostalgia por el retorno de regímenes autoritarios y a la implementación de medidas represivas, las cuales, como se ha señalado desde el tiempo de la colonia, han resultado infructuosas para dar respuesta al problema Este fenómeno, aunado a escasas políticas de inversión social, reducción de pobreza, educación y servicios de salud, genera un vacío en las comunidades afectadas, que rápidamente es llenado por las OC.

La economía criminal ciertamente genera mucho capital y oportunidades de empleo para las grandes masas desempleadas o subempleadas (UNODC, 2007; Richani, 2007). Asimismo las deportaciones masivas desde los EEUU, entre 1998 y 2005 alrededor de 160,000 personas y 46,000 convictos fueron deportados a Centro América, contribuyen no solo a generar una mayor sobrecarga de los sistemas sociales, sino también permite que se intercambien experiencias entre las prácticas de las OC norteamericanas y las locales (Jütersonke, Muggah \& Rodgers, 2009).

\subsection{Condicionantes social-culturales}

En el ámbito socio-cultural son varios los factores que están incidiendo en el fenómeno de las OC. En primer lugar tenemos que existen en las sociedades del área objeto de estudio bajos niveles de control social, los cuales se expresan en redes sociales débiles y de baja calidad, poca cohesión social intra y entre las comunidades, poca participación comunitaria, altos niveles de desintegración familiar y elevados niveles de "stress" socio económico. Además la violencia se ha enquistado en las comunidades del área donde bajo su constante exposición, tiende a tornarse en una manera legítima para la resolución de conflictos. Asimismo, muchas personas angustiadas ante la falta de seguridad y justicia del Estado, optan por tomar la justicia por sus propias manos. Igualmente, se está frente a una sociedad mediatizada en la cual la principal información sobre el crimen es provista por los diversos medios de comunicación social (MCS).

Estos medios están en su mayoría orientados a especular con la violencia, generan en la población una percepción de inseguridad mayor a la que 
en realidad existe, propiciando a su vez una mayor desconfianza de la población en sus autoridades. Los MCS tienden a vender el concepto en el cual los delincuentes están presentes dondequiera y son por doquier temibles, perteneciendo a un mundo totalmente distinto, sin relación a la existencia cotidiana y familiar (UNODC, 2007; Focault, 2002). La elevada percepción de inseguridad, a su vez, genera que los servicios privados de seguridad se proliferen, situación que propicia: a) La inequidad en la distribución de la seguridad, en la cual las comunidades con mayor poder adquisitivo son patrulladas preventivamente por los miembros de los agencias de seguridad privada y la policía, mientras que las comunidades pobres son patrulladas represivamente por la policía; b) La seguridad deviene en una mercancía la cual responde al mercado y no a los intereses más elevados de la sociedad y; c) Las agencias de seguridad privada se convierten en verdaderos ejércitos privados, los cuales en la mayoría de casos superan en efectivos a las policías de la región.

Los otros factores sociales que inciden en el problema del crimen organizado que nos atiende, es el elevado índice de urbanización que está presente en las sociedades del área. En Latinoamérica el $75 \%$ de la población es urbana. Este proceso de urbanización ha ido acompañado, como lo fue en la época colonial, de una población "flotante" que se concentra en los márgenes de las grandes ciudades y pertenecen a las escalas más bajas de la sociedad.

Estas comunidades viven en una situación precaria, plagada de una severa penuria, violencia, alcohol, drogas, prostitución y promiscuidad. Circunstancias que las tornan en fácil presa de las OC que las utilizan como colaboradores o perpetradores para cometer sus fechorías y sus comunidades se convierten en lugares idóneos para buscar refugio. Una estadística resulta reveladora sobre el efecto de las ciudades en el crimen, un hogar en una ciudad de más de 1 millón de habitantes tiene el doble de probabilidad de ser victimizado que un hogar en una ciudad con menos de 20 mil habitantes (Cuadra, 2003; Elbert, 2004; Brennan-Galvin, 2002).

\subsection{Condicionantes económicos}

Los factores económicos que están incidiendo en el fomento de la OC son producto en parte de la implementación de las medidas neoliberales y de ajuste estructural durante la década de los noventa del siglo pasado. Estos factores se han agravado con la crisis financiera del año 2007 desatada por la avaricia de los grandes financistas del mundo. A manera de ejemplo, Bernard L. Madooff, ex presidente de NASDDAQ fue detenido por estafar la 
increíble suma de 50 mil millones de dólares a inversionistas ${ }^{14}$. Producto de las situaciones expuestas son:

a) Altas tasas de desempleo en el área resultado de una contracción económica que para el caso de México alcanzó para la primera mitad de 2009 un 9.2 \%. De igual forma fueron impactadas las economías de los demás países centroamericanos. Esta contracción obedeció a una decreciente demanda externa, una baja de los precios de las materias primas y la contracción del consumo y la inversión pública y privada (United Nations, 2010).

b) Una elevada inequidad en la distribución de la riqueza, en la cual una minúscula élite vive en la opulencia mientras las grandes mayorías languidecen en la pobreza. Según el índice de GINI para el año 2009, la región Mesoamericana y del Caribe se encuentra con un índice entre 60 y 45, lo que denota una gran desigualdad en la distribución del ingreso y la riqueza ${ }^{15}$.

c) Otra consecuencia económica a tener muy en cuenta es el elevado costo que la violencia, el narcotráfico y el crimen organizado tiene para los diversos Estados. Un estudio calculaba en el año 2008 que los gobiernos centroamericanos gastaron alrededor de 6 mil 500 millones en seguridad o sea el $7.7 \%$ del Producto Interno Bruto de la Región ${ }^{16}$, en México se ha calculado que dicho costo ha sido en los últimos diez años la espeluznante cifra de 94 mil 300 millones de dólares o el $15 \%$ de su Producto Interno Bruto ${ }^{17}$.

d) La existencia de un inmenso mercado informal en la región tiene también sus efectos nocivos. La existencia de "mercados negros" siempre ha estado emparejada con la presencia de las OC o mafias. Estos mercados informales no recurren a los mecanismos legales establecidos para saldar sus cuentas y deudas, sino que éstas son tramitadas a través del accionar de las OC o mafias.

También es de hacer notar que las inmensas cantidades de dinero que son generadas por las actividades criminales tienen que ser canalizadas tarde o temprano en el mercado formal. Esta situación crea una relación que muchas veces no se quiere enfrentar, la relación existente entre el mercado "legal" e "ilegal". Hay muchas

14. http://www.eleconomista.es/mercados-cotizaciones/noticias/917357/12/08/El-inversor-Bernard-L-Madoff-detenido-por-un-fraude-que-podria-ascender-a-50000-millones-de-dolares.html, consultado el 11.12.2012.

15. El Índice GINI mide la desigualdad en una tasa en que 0 representa la perfecta igualdad en la distribución de la riqueza y 100 la completa desigualdad. http://en.wikipedia.org/wiki/List of countries by income equality, consultado el 11.12.2012.

16. http://mexidata.info/id1949.html, consultado el 11.12.2012.

17. http://www.poder360.com/article detail.php?id article=710, consultado el 11.12.2012. 
OC que están insertando sus ganancias en el mercado legal (bienes raíces, casinos, clubes nocturnos, hoteles, restaurantes, bancos, "car wash", etc.) y de esta manera están "limpiando" o "lavando" sus activos. Cálculos del Fondo Monetario Internacional sitúan el valor del lavado de dinero en el año 2009 en 1.6 trillones de dólares ${ }^{18}$. El lavado de dinero no solo es una amenaza a la seguridad nacional e internacional dado que financia las actividades de las OC y paga la corrupción de funcionarios, burócratas y agentes de autoridad, sino que también genera problemas económicos. La reinversión de fondos recaudados por medio de las actividades ilegales en compañías legales socava la economía legítima a la vez que trastorna el equilibrio natural del mercado (Brennan-Galvin, 2002).

f) Finalmente el factor tal vez más importante que promueve la propagación de las OC es que resulta ser una actividad inmensamente lucrativa, en la cual individuos que han nacido en ambientes repletos de todo tipo de desventajas y vulnerabilidades pueden fácilmente acceder a grandes riquezas.

El negocio ilegal es caracterizado por sus bajos riesgos (dada la gran impunidad existente) y su gran rentabilidad; muchas $\mathrm{OC}$ realizan inversiones sociales en las comunidades donde se refugian, Ilenando el vacío que deja la displicencia estatal y ganando la confianza y apoyo de la comunidad, quienes los ven como unos "Robin Hood" modernos, a los que los jóvenes buscan emular. El valorar a las personas por lo que tienen y no por lo que son, parece ser un mal endémico de nuestra época.

\section{Reflexiones finales}

El descubrimiento de América propició la transferencia de tecnología, plantas, animales y enfermedades a una enorme escala ( $O$ ' Rourke \& Williamson, 2002). Asimismo esta época coincide con la etapa de fortalecimiento y difusión de la mentalidad burguesa. Durante todo el tiempo de la Colonia hasta nuestros días se puede apreciar que la región Mesoamericana y del Caribe ha estado ligada a operaciones criminales de índole transnacional. Primero con el accionar de piratas, contrabandistas y bandidos (a partir de este momento se identificarán con las siglas PCB) y posteriormente con la actividad de las OC dedicadas a la explotación de todo tipo de operaciones ilícitas.

18. http://www.fatf-gafi.org/pages/faq/moneylaundering/, consultado el 11.12.2012. 
Entre los primeros y los últimos hay un vínculo que los une a través del tiempo y es que los individuos que conformaban y conforman dichas organizaciones comparten la misma mentalidad burguesa. Lo anterior se asevera porque tanto los criminales de antaño como los actuales, denotan las siguientes características propias de ese tipo de mentalidad: la racionalidad, el dominio sobre el mundo, la importancia del ascenso socio-económico y la acumulación de riqueza.

\subsection{La racionalidad}

Los criminales han sido siempre actores racionales; han analizado detenidamente sus opciones bajo el prisma de la evaluación costo/beneficio. También conforman organizaciones de aprendizaje que se perfeccionan a través de su experiencia. En este tipo de organización la información fluye entre todos sus miembros a todo nivel y en todas sus estructuras, situación que les permite estar en un proceso de transformación continua, por medio del cual se adaptan con extrema facilidad a los retos, a las amenazas y a las oportunidades que se les presentan.

En este mundo la picardía y la astucia han sido siempre sumamente valiosas, así como también la capacidad de análisis para descifrar las causas y efectos de los acontecimientos que pueden tener inherencia en sus actividades ilícitas, para poder predecir sus efectos, evitar los posibles daños que puedan ocasionar y aprovecharse de las oportunidades que presentan. La mayoría de los líderes de estas organizaciones han sido y siempre serán personas extremadamente inteligentes y prácticas. Algunos de ellos a pesar de no contar con una adecuada educación formal tienen una enorme capacidad para organizar, dirigir y administrar sus OC, muchas de las cuales son verdaderos imperios. Además poseen una gran habilidad para consensar y dirimir exitosamente los conflictos que se les presentan. La única diferencia entre uno de estos "capos" del crimen y los grandes capitanes de la industria, es que los primeros utilizan con mayor frecuencia la violencia para alcanzar sus fines.

\subsection{El dominio sobre el mundo}

En la década de los ochenta se estrenó la película "Cara Cortada" por medio de la cual se presentaba la versión de Hollywood del crimen organizado. Este filme tuvo un tremendo éxito taquillero e insertó en el imaginario popular el glamoroso tipo de vida, de acción, de sexo y de violencia presente en el mundo del narcotráfico. La frase inolvidable de este filme "El Mundo es Mío" refleja la esencia de la mentalidad burguesa 
de las OC, su intención de dominar el mundo en que operan, donde nada ni nadie los detendrá para alcanzar sus metas propuestas. Los criminales desde siempre se han valido de la técnica y la tecnología para hacer más eficientes sus operaciones. Respetan el conocimiento científico, el cual pagan con buenos dólares para poner a su servicio.

Lo importante para los miembros de las OC es el presente, la realidad operativa, no se preocupan por lo trascendente o allende a la realidad. Aunque muchos muestran un fervor religioso, éste va más ligado a ser una especie de cábala para beneficiar sus "negocios" o una abierta práctica del satanismo para adquirir poder.

\subsection{La importancia del ascenso socio-económico y la acumulación de riqueza}

El logro del ascenso socio-económico y la acumulación de riqueza, característica propia de la mentalidad burguesa, fue un objetivo de los PCB como lo es ahora para los miembros de las OC. La idea de involucrarse en el mundo criminal tiene en muchos casos como punto de partida el ser la única salida viable al mundo de miseria en que muchos de los criminales nacen. Parte de su ansia de triunfar es el poder incorporarse con tremendo fervor al consumismo, al tipo de vida que ven a través de los programas, videos y anuncios de televisión.

El acumular riquezas es uno de los principales objetivos de los miembros de las OC. Muchos de éstos criminales se han condenado al llamar la atención de las autoridades por alardear de su riqueza, comprando automóviles de lujo, joyas, ostentosas mansiones, yates y dilapidando el dinero a manos Ilenas. Pretenden esconder su ausencia de gracia social y educación vistiéndose estrafalariamente, con ropa y accesorios de lujo y al alcanzar elevados ingresos, tienden a involucrarse en deportes y hobbies propios de millonarios.

\subsection{Corolario}

Entre los fenómenos de los PCB y las OC existe un paralelismo que se refleja en las circunstancias siguientes:

a. La importancia de mantener el valor de la palabra dada. En un mundo oscuro donde no se puede recurrir a contratos para establecer derechos y obligaciones, las transacciones y negocios se hicieron y se hacen sobre la base de la reputación. 
b. El carácter transnacional de ambos tipos de criminalidad, la pasada y actual, resulta obvio, el principal enemigo lo fueron y son los Estados soberanos. La descoordinación que existió en las administraciones coloniales hoy es emulada por los gobiernos nacionales, situación que favoreció y favorece en la actualidad las transacciones ilícitas. Los PCB y las OC nunca consideraron las fronteras (durante la colonia entre Virreinatos, Capitanías Generales y los territorios bajo dominio de otras potencias europeas y actualmente las delimitaciones territoriales y de soberanía entre los Estados nacionales) como un obstáculo sino como una ventaja. La porosidad de las fronteras era una realidad tanto en la Colonia como en la actualidad.

c. La corrupción fue y es un instrumento utilizado tanto por los PCB como las OC con la finalidad de materializar sus propósitos. La corrupción es una realidad que corroe las instituciones nacionales en la actualidad como lo fue en el tiempo de la Colonia.

d. La canalización de los ingresos provenientes de las actividades ilegales al mercado legal fue una práctica en el pasado como lo es en el presente, su daño a las economías y al funcionamiento del mercado fue y es tan vigente antaño como ahora.

e. La distribución de los ingresos producto del crimen en las comunidades que albergaban a los PCB y albergan a las OC también es otra medida que se utilizó y utiliza con éxito para granjearse su apoyo; así mismo, la utilización de poblaciones locales, ya sea en conflicto con las autoridades estatales o por el puro beneficio que les acarrea y acarreaba ha sido otra de las tácticas empleadas tanto por los PCB como las OC.

f. La migración en masa es otra característica que comparten ambos fenómenos. Durante la colonia, la migración forzada ${ }^{19}$ de millones de esclavos ${ }^{20}$ para trabajar en las minas y plantaciones; en la actualidad los millones de migrantes que escapan de la violencia, mucha de la cual es generada por las OC para ir a ser explotados en el Norte.

g. El Imperio español y los actuales Estados nacionales del área Mesoamericana y El Caribe han implementado el mismo tipo

19. La migración forzada, según el Diccionario de Acción Humanitaria y Cooperación de Desarrollo, es el movimiento de población fuera de su lugar de origen o de residencia habitual, de carácter invo. luntario, temporal o permanente y por lo general a gran escala, motivado por la presión -o la amena. za- de factores externos actuando aisladamente o en conjunción. http://www.dicc.hegoa.ehu.es/listar/ mostrar/143, consultado el 11.12.2012.

20. El estudio de la UNESCO denominado "La Ruta del Esclavo" calcula que durante los 400 años que duró el tráfico de esclavos vinieron a América 11 millones de africanos. http://www.ceibal.edu.uy/contenidos/areas conocimiento/cs sociales/esclavitud/cuntos esclavos vinieron a amrica.html, consultado el 11.12.2012. 
de medidas represivas (más patrullajes, despliegue de fuerza, modificaciones legales, endurecimiento de las condenas, privatización de la seguridad) y han realizado los mismos esfuerzos todo lo cual resultó en su momento y resulta ahora infructuoso, ineficaz e incapaz de solucionar el problema.

h. El paralelismo más irónico de todos resultó ser que así como las potencias europeas durante la colonia apoyaron y fomentaron la piratería; luego de haber desatado a los "perros del mar" les tocó enfrentarlos cuando éstos se salieron fuera de control. Igualmente acaeció con el gobierno de EEUU, que durante tuvo vigencia la Doctrina de Seguridad Nacional, apoyaron a muchos de los "capos" de la droga (que ofrecían valiosos contactos clandestinos, canales de infiltración, "músculo", experticia y financiamiento invisible y como buenos hombres de empresa eran fervientes anti-comunistas) para contener los movimiento insurreccionales en América Latina, para luego también tener que enfrentarlos cuando éstos se salieron también de control (Gootenberg, 2009). El adagio "el enemigo de mi enemigo es mi amigo" no tuvo en ninguno de los casos buenos resultados. También cabe destacar que tanto para los PCB como para las OC la experticia con las armas siempre fue una habilidad valorada, situación que no sorprende en un mundo que se viste de sangre y en el cual prevalece la violencia. Irónicamente muchos de los mercenarios que se utilizaron y se utilizan fueron formados y entrenados militarmente por los Estados nacionales (Zetas y el Spetsnaz ${ }^{21}$ para nombrar algunos).

21. Spetsnaz son las fuerzas de operaciones especiales rusas, muchos de sus miembros han pasado a trabajar para las OC, luego de la caída del Muro de Berlín. 


\section{Cuadro 3.}

\section{Características de adversarios}

\begin{tabular}{|c|c|}
\hline $\begin{array}{l}\text { Instituciones involucradas en seguridad } \\
\text { pública (Ministerio de Seguridad Pública, } \\
\text { Policía, Sistema Judicial, Sistema } \\
\text { Penitenciario, Fuerza Armada) }\end{array}$ & $\begin{array}{c}\text { Actores sociales que actúan } \\
\text { en la ilegalidad (Crimen organizado, } \\
\text { carteles, pandillas) }\end{array}$ \\
\hline $\begin{array}{ll}\checkmark & \text { Reactivas } \\
\checkmark & \text { Descoordinación } \\
\checkmark & \text { Saturación } \\
\checkmark & \text { Recursos limitados } \\
\checkmark & \text { Son organizaciones basadas en normas } \\
& \text { y reglas. Son difíciles de cambiar, poco } \\
& \text { dinamismo. }\end{array}$ & 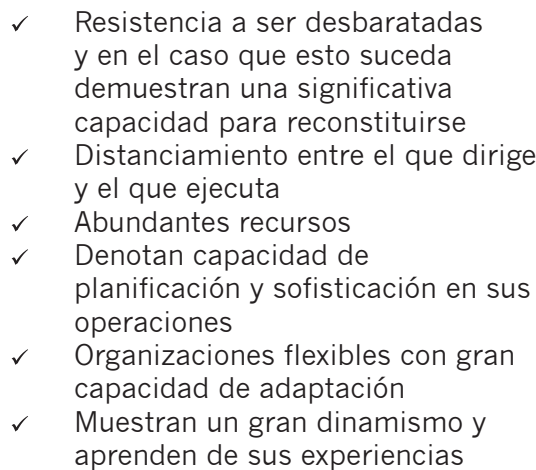 \\
\hline
\end{tabular}

Fuente: Elaboración propia.

Ante todo lo expuesto cabe hacerse una última pregunta ¿Qué nos depara el futuro? La verdad que el problema del crimen, tanto en el pasado con los PCB y ahora con las OC fue y es un problema multidimensional y de gran complejidad. La única manera de resolver el problema sería el de advertir las causas que lo generan, muchas de las cuales son de naturaleza culturalsocial y económica, para poder mitigar o eliminar las mismas. Cualquier otra forma con que se quiera enfrentar la criminalidad está condenada desde un principio al fracaso. En el cuadro 3 se comparan los adversarios y en él podemos apreciar que la balanza favorece a los grupos criminales.

Además de la obvia desventaja en que se encuentran las instituciones estatales para enfrentar el crimen organizado, hay que tomar en cuenta que éstas se potencian al estar constantemente las OC procurando corromperlas e infiltrarlas. Agravando la situación los factores de índole político y la naturaleza burocrática de sus instituciones que genera una serie de limitantes en el proceso de toma de decisiones que las inmovilizan o tornan lentas. Finalmente se considera también que una gran parte del problema consiste en que se quiere enfrentar con instituciones creadas en el Siglo XVIII la criminalidad del siglo XXI. No hay que olvidar jamás que "pueblo que olvida su historia está condenado a repetirla". 


\section{Bibliografía}

\section{Libros e informes}

1. De Pazzis Pi Corrales, Magdalena, (2001). "La Armada de los Austrias", Real Sociedad Económica de Amigos del País, Sevilla.

2. Foucault, Michel. (2002). "Vigilary Castigar", Siglo XXI, Editores Argentina S.A.

3. García, Luis; Carrande, Ramón. (1960) "Sobre los Burgos y los Burgueses de la España Medieval (notas para la historia de los orígenes de la burguesía)", Real Academia de la Historia, Madrid.

4. Informe Sub-Regional Centro América y Panamá. (2006). "Armas Pequeñas y Livianas". FLACSO, San José, Costa Rica.

5. Linz, Juan J. (2000). "Totalitarian an Authoritarian Regimes," Lynne Rienner Publishers, Boulder, Colorado, EE.UU.

6. Romero, José Luis. (1999). "Estudio de la Mentalidad Burguesa", Alianza Editorial, Buenos Aires, Argentina.

7. Romero, José Luis. (2001). "Latinoamérica: La Ciudades y las Ideas", Siglo XXI, Buenos Aires, Argentina.

8. Rubio Mañé, J. Ignacio. (1983). "El Virreinato I: Orígenes Jurisdicciones, $y$ dinámica social de los virreyes", Fondo de Cultura Económica, UNAM, México.

9. Sills, David L. ed. (1968). "International Encyclopedia of the Social Sciences", Macmillan Company, New York, EE.UU.

10. Sobrevilla, David. (2006). "Filosofía y Globalización”. Universidad de Lima, Perú.

11. Stohl, Rachel \& EJ, Hogendoorn. (2010). "Stopping the Destructive Spread of Small Arms: How Small Arms and Light Weapons Proliferation Undermines Security and Development", Center for American Progress, EE.UU.

12. United Nations, (2010), "World Economic Situation and Prospects", United Nations, New York, EEUU.

[http://www.un.org/en/development/ desa/policy/wesp/wesp archive/2010wesp.pdf, consultado el 11.12.2012].

13. United Nations Office on Drugs and Crime [UNODC]. (2002). "Results of a pilot survey of forty selected organized criminal groups in sixteen countries". [http://www.unodc. org/pdf/crime/publications/ consultado el 11.12.2012].

14. United Nations Office on Drugs and Crime [UNODC]. (2007). "Crime and Development in Central America". [http://www.unodc. org/pdf/crime/publications/, consultado el 15.01.2013].

15. United Nations Office on Drugs and Crime [UNODC]. (2010). "World Drug Report", http://www.unodc.org/pdf/crime/ publications/, consultado el 11.12.2012].

\section{Revistas}

1. Boot, Max. (2009). "Pirates then and now", Foreign Affairs, Volume 88, Issue 4, July/ August 2009.

2. Brennan-Galvin, Ellen. (2002). "Crime and violence in an urbanizing world", Journal of International Affairs; Fall 2002; 56, 1; ABI/ INFORM Global.

3. Brown, Vera Lee. (1928). "Contraband Trade: A Factor in the Decline of Spain's Empire in America", The Hispanic American Historical Review, Vol. 8, No. 2 (May, 1928), pp. 178. 189.

4. Cuadra, Sergio. (2003). "Globalization and the capacity of violence to transform social spaces: Some Critical points of the Latin America Debate". Crime, Law and Social Change; Mar 2003; 39, 2; ABI/INFORM Global. Pp. 163.173.

5. Elbert, Carlos Alberto. (2004). "Rebuilding Utopia? Critical Criminology and the Difficult Road of Reconstruction in Latin America". Crime Law and Social Change, 41, May 2004, pp 385-395.

6. Fajardo, Luis E. (2002). "La corrupción heredada: pasado colonial, sistema legal y desarrollo económico en Colombia", Revista No. 12 junio de 2002, Revista de Estudios Sociales, Universidad los Andes, Bogotá.

7. Fuchs, Barbara. (2000). "Faithless Empires: Pirates, Renegades, and the English Nation", ELH, Vol. 67, No. 1 (Spring, 2000), pp. 45. 69, The Johns Hopkins University Press.

8. Gootenberg, Paul. (2009). "Talking About the Flow: Drugs, Borders, and the Discourse of Drug Control", Cultural Critique, 71, Winter 2009, pp. 13-46, Published by University of Minnesota Press.

9. Jütersonke, Oliver; Robert Muggah \& Dennis Rodgers. (2009). "Gangs, Urban Violence, and Security Interventions in Central America", Security Dialogue, p. 40.

10. Lokken, Paul. (2004). "Useful Enemies: Seventeenth-Century Piracy and the Rise of Pardo Militias in Spanish Central America", Journal of Colonialism and Colonial History, Volume 5, Number 2, Fall 2004, Project Muse.

11. Nachbar, Thomas B. (2005). "Monopoly, 
Mercantilism, and the Politics of Regulation". Virginia Law Review, Vol. 91, p. 1313, 2005.

12. O' Rourke, Kevin H \& Jeffrey J., Williamson. (2002). "When did Globalization begin?", European Review of Economic History, Cambridge University Press, vol.6 (01), p. 25.30, April.

13. Sanders, G. Earl. (1977). "CounterContraband in Spanish America: Handicaps of the Governors in the Indies", The Americas, Vol. 34, No. 1 (Jul., 1977), pp. 59.80, Published by: Catholic University of America Press on behalf of Academy of American Franciscan History.

14. Zahedieh, Nuala. (1986). The Merchants of Port Royal, Jamaica, and the Spanish Contraband Trade, 1655-1692. The William and Mary Quarterly, Third Series, Vol. 43, No. 4 (Oct., 1986), pp. 570-593, Omohundro Institute of Early American History and Culture.

\section{Páginas web}

1. Ventieri, Nicolás. (2010). "Contrabando en la América Colonial: Tráfico ilegal, ¿Élites locales autónomas?". [http://suite101.net/ article/contrabando-en-la-america-coloniala12669\#axzz20IT47LHf, consultada el 11.12.2012].

2. Richani, Nazih. (2007). Systems of Violence and their Political Economy in Post-Conflict Situations. [http://www.cmi.no/sudan/ resources.cfm?id=579-systems-of-violenceand-their-political-economy-in-post-conflictsituations, conultada el 11.12.2012].

3. Owens, J. B. (2005). "Smuggling through Spain: A neglected sixteenth-century commercial connection between the Mediterranean and the Atlantic", [http:// www.usc.es/estaticos/congresos/histec05/ b24 owens.pdf, consultada el 11.12.2012].

4. Tomich, Dale. (2008). "The Order of Historical Time: The Longue Durée and Micro-History", Fernand Braudel Center Colloquium to Commemorate the 50th Anniversary of Fernand Braudel, Histoire et sciences sociales: La longue durée, Annales E.S.C., XIII, 4, 1958, October 24-25, 2008, Binghamton University Binghamton, NY, EE.UU.

[http://www2.binghamton.edu/fbc/ archive/tomich102508.pdf,] consultada el 11.12.20.12

\section{Otros}

1. Ward, Eliot \& Dunbar, Christopher. (1988). "Imperial Panama: Commerce and Conflict in Isthmian America", 1550-1750. Dissertation presented to the University of Florida in partial fulfillment of the requirements for the Degree of Doctor of Philosophy.

2. Stringham, Joseph. (2009). Conferencia "Amenazas Futuras". Programa de Asistencia para Combatir el Terrorismo, Miami, Florida, 18 agosto. 